LIGHT POLLUTION HANDBOOK 


\section{ASTROPHYSICS AND SPACE SCIENCE LIBRARY}

VOLUME 322

\section{EDITORIAL BOARD \\ Chairman}

W.B. BURTON, National Radio Astronomy Observatory, Charlottesville, Virginia, U.S.A. (burton@starband.net); University of Leiden, The Netherlands (burton@strw.leidenuniv.nl)

\section{Executive Committee}

J. M. E. KUIJPERS, Faculty of Science, Nijmegen, The Netherlands

E. P. J. VAN DEN HEUVEL, Astronomical Institute, University of Amsterdam, The Netherlands

H. VAN DER LAAN, Astronomical Institute, University of Utrecht, The Netherlands

\section{MEMBERS}

I. APPENZELLER, Landessternwarte Heidelberg-Königstuhl, Germany

J. N. BAHCALL, The Institute for Advanced Study, Princeton, U.S.A.

F. BERTOLA, Universitá di Padova, Italy

J. P. CASSINELLI, University of Wisconsin, Madison, U.S.A.

C. J. CESARSKY, Centre d'Etudes de Saclay, Gif-sur-Yvette Cedex, France

O. ENGVOLD, Institute of Theoretical Astrophysics, University of Oslo, Norway

R. McCRAY, University of Colorado, JILA, Boulder, U.S.A.

P. G. MURDIN, Institute of Astronomy, Cambridge, U.K.

F. PACINI, Istituto Astronomia Arcetri, Firenze, Italy

V. RADHAKRISHNAN, Raman Research Institute, Bangalore, India

K. SATO, School of Science, The University of Tokyo, Japan

F. H. SHU, University of California, Berkeley, U.S.A.

B. V. SOMOV, Astronomical Institute, Moscow State University, Russia

R. A. SUNYAEV, Space Research Institute, Moscow, Russia

Y. TANAKA, Institute of Space \& Astronautical Science, Kanagawa, Japan

S. TREMAINE, CITA, Princeton University, U.S.A.

N. O. WEISS, University of Cambridge, U.K. 


\section{LIGHT POLLUTION HANDBOOK}

by

KOHEI NARISADA

and

DUCO SCHREUDER

照 Springer 
A C.I.P. Catalogue record for this book is available from the Library of Congress.

ISBN 978-94-015-7058-9

ISBN 978-1-4020-2666-9 (eBook)

DOI $10.1007 / 978-1-4020-2666-9$

Printed on acid-free paper

Cover page: 'Caféterras bij avond (place du forum)'

Vincent van Gogh. Kröller-Müller Museum, Otterlo

Typesetting: Jan Faber, LINE UP Tekstproducties bv, Groningen, The Netherlands

springeronline.com

All Rights Reserved

(C) Springer Science+Business Media Dordrecht 2004

Originally published by Springer 2004

Softcover reprint of the hardcover 1st edition 2004

No part of this work may be reproduced, stored in a retrieval system, or transmitted in any form or by any means, electronic, mechanical, photocopying, microfilming, recording or otherwise, without written permission from the Publisher, with the exception of any material supplied specifically for the purpose of being entered and executed on a computer system, for exclusive use by the purchaser of the work. 
to Tsuyako and Fanny 


\section{Contents}

Preface

XIX

1 Preamble 1

1.1 There is only one Earth 1

1.1.1 The philosophy of the environment 1

1.1.2 The philosophy of the night 4

$\begin{array}{ll}1.2 & \text { Light pollution and energy conservation } \\ 12\end{array}$

1.2.1 Spill light and light pollution $\quad 12$

1.2.2 Energy consumption for outdoor lighting $\quad 15$

1.2.3 Energy losses as a result of light pollution 16

1.2.4 Environmental impact of light pollution 17

$\begin{array}{ll}1.2 .5 & \text { Remedial measures } \\ 1.2 .6 & 18\end{array}$

1.2.6 Implementing remedial measures 20

$\begin{array}{ll}1.3 & \text { International organizations }\end{array}$

$\begin{array}{lll}1.3 .1 & I C S U & 27\end{array}$

$\begin{array}{lll}1.3 .2 & I A U & 28\end{array}$

$\begin{array}{lll}1.3 .3 & \text { CIE } & 28\end{array}$

1.3.4 The International Dark-Sky Association 30

References $\quad 31$

$2 \quad$ Aim and purpose of outdoor lighting 37

2.1 The contribution of outdoor lighting to the efficiency of human 37

2.1.1 Functional activities $\quad 37$

2.1.2 Non-functional activities 38

2.1.3 The indirect contribution of outdoor lighting to the efficiency of
human activities in daytime

2.2 The contribution of outdoor lighting to commercial activities at night 39

2.3 General characteristics of outdoor lighting 40

$\begin{array}{lll}2.4 & \text { City beautification } & 41\end{array}$

2.4.1 Streets and squares $\quad 42$

2.4.2 Historical buildings and sites 43

2.4.3 Trees, flowers, parks and gardens $\quad 44$

2.4.4 Monuments 44

2.4.5 Rivers, ponds, fountains, bridges 44

2.5 Lighting for motorised road traffic $\quad 44$ 
2.5.1 Road lighting as functional lighting 44

2.5.2 Accident prevention $\quad 45$

2.5.3 The relation between public lighting and crime prevention and reduction 45

2.5.4 Amenity 46

2.5.5 Construction or maintenance sites of roads 47

2.5.6 Intersections and junctions $\quad 47$

$\begin{array}{lll}2.5 .7 & \text { Bus terminals } & 48\end{array}$

$2.6 \quad$ Automobile lighting $\quad 49$

$2.7 \quad$ Sports lighting $\quad 50$

2.7.1 Lighting for recreational sports $\quad 51$

2.7.2 Lighting for large-size sports stadiums

$2.8 \quad$ Industry and commerce $\quad 52$

2.8.1 Industry $\quad 52$

2.8.2 Lighting for commerce 54

$2.9 \quad$ Agriculture, fishery and forest burning 55

2.9.1 Greenhouses $\quad 55$

2.9.2 Fishery 57

2.9.3 Forest burning $\quad 57$

$\begin{array}{ll}\text { References } & 57\end{array}$

$3 \quad$ What is light pollution? $\quad 61$

$\begin{array}{lll}3.1 & \text { The natural background radiation } & 61\end{array}$

$\begin{array}{lll}3.2 & \text { Direct light; light intrusion } & 64\end{array}$

$\begin{array}{lll}3.3 & \text { Sky glow } & 66\end{array}$

3.3.1 The effect of sky glow 66

3.3.2 Methods of astronomic observations $\quad 67$

$\begin{array}{lll}\text { 3.3.3 Reflected light } & 68\end{array}$

3.4.4 Horizon pollution $\quad 69$

3.4 The environmental approach towards reduction of light intrusion $\quad 71$

$\begin{array}{lll}3.4 .1 & \text { Zoning } & 71\end{array}$

$\begin{array}{ll}3.4 .2 \text { Curfew } & 73\end{array}$

$\begin{array}{ll}\text { References } & 74\end{array}$

$4 \quad$ Adverse effects of light pollution $\quad 79$

$\begin{array}{lll}4.1 & \text { Annoyance } & 79\end{array}$

4.2 Effects on nature $\quad 80$

4.2.1 Natural parks and nature reserves $\quad 80$

4.2.2 The landscape $\quad 85$

$\begin{array}{lll}4.3 & \text { Influence on plants } & 91\end{array}$

4.3.1 The influence of light on plants 91

4.3.2 The influence of light pollution on plants 92

4.3.3 Greeneries 93

$\begin{array}{lll}4.4 & \text { Influence on animals } & 94\end{array}$

4.4.1 Animals in general $\quad 94$

$\begin{array}{lll}4.4 .2 & \text { Insects } & 95\end{array}$

4.4.3 Birds 96

$\begin{array}{lll}4.5 & \text { Health effects of light } & 97\end{array}$ 
4.5.1 Image forming and non-image forming effects of light 97

4.5.2 Influence of light on the biorhythm 100

$\begin{array}{ll}\text { 4.5.3 Phototherapy } & 102\end{array}$

4.5.4 Nuisance caused by outdoor lighting 103

$\begin{array}{ll}4.5 .5 & \text { Nuisance caused by assimilation lighting } \\ 4.5 .6 & 104\end{array}$

4.5.6 Nuisance caused tennis court lighting $\quad 105$

4.5.7 Light nuisance and the general population 106

$\begin{array}{ll}\text { References } & 108\end{array}$

$5 \quad$ Light pollution and astronomy $\quad 115$

$\begin{array}{lll}5.1 & \text { Interference with astronomical observation } & 115\end{array}$

5.1.1 Contrast observation $\quad 115$

$\begin{array}{ll}\text { 5.1.2 The sky glow formula } & 116\end{array}$

$\begin{array}{ll}\text { 5.1.3 Walker's Law } & 117\end{array}$

$\begin{array}{lll}5.2 & \text { Light pollution today } & 118\end{array}$

5.2.1 Distribution in place and time of light pollution 118

5.2.2 Local measurements of light pollution 119

$\begin{array}{ll}\text { 5.2.3 Regional measurements of light pollution } & 121\end{array}$

5.3 'The first world atlas of the artificial night sky brightness' 125

$\begin{array}{lll}\text { 5.3.1 Publicity impact } & 125\end{array}$

5.3.2 The technical basis of the Atlas 126

$\begin{array}{lll}5.3 .3 \text { Results } & 126\end{array}$

$\begin{array}{ll}\text { 5.3.4 Upward emission } & 128\end{array}$

5.3.5 The spread-function of the light pollution 128

$\begin{array}{lll}5.4 & \text { Increase in sky glow } & 131\end{array}$

$\begin{array}{ll}\text { References } & 134\end{array}$

$6 \quad$ Limiting values for light pollution $\quad 139$

$\begin{array}{lll}6.1 & \text { Zoning and curfew } & 139\end{array}$

6.2 CIE proposals for light pollution limits $\quad 141$

6.2.1 CIE Guidelines for minimizing sky glow 141

6.2.2 CIE Guide on the limitation of obtrusive light 143

6.2.3 Extension of the CIE guidelines for minimizing sky glow 145

$\begin{array}{ll}\text { References } & 147\end{array}$

$7 \quad$ Recommendations $\quad 151$

$\begin{array}{lll}7.1 & \text { General recommendations } & 151\end{array}$

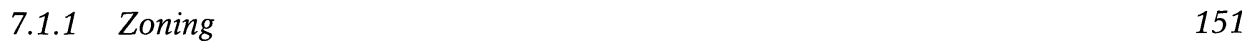

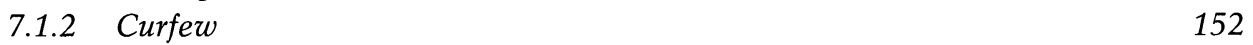

7.1.3 Subdivisions 153

7.1.4 Classification of luminaires 153

7.1.5 The colour of the light 159

$\begin{array}{lll}7.2 & \text { Intrusive light } & 160\end{array}$

7.2.1 Recommendations regarding direct light intrusion - residents 160

7.2.2 Summary of recommendations 165

7.3 Recommendations to restrict the interference by light of astronomical observations 
7.3.1 Direct light 166

7.3.2 Sky glow 166

$\begin{array}{ll}\text { References } & 171\end{array}$

$8 \quad$ Vision and visibility $\quad 175$

8.1 The anatomy and physiology of the human visual system 175

$\begin{array}{lll}8.1 .1 & \text { The overall anatomy } & 175\end{array}$

8.1.2 The optical elements 176

8.1.3 The retina and the photoreceptors 180

8.1.4 Cones and rods 181

8.1.5 The optical nerve and the brain 182

8.2 The functions of the human visual system 186

8.2.1 The sensitivity of the eye 186

8.2.2 Photopic vision; the $V_{\lambda}$-curve 187

8.2.3 Scotopic and mesopic vision 190

$\begin{array}{ll}\text { 8.3 Colour vision and colorimetry } & 197\end{array}$

8.3.1 The importance of colour 197

$\begin{array}{ll}\text { 8.3.2 Colour vision physiology } & 199\end{array}$

8.3.3 The spectral sensitivity curves of separate kinds of cones 201

8.3.4 The Purkinje-effect 203

8.3.5 Mesopic brightness impression $\quad 207$

$\begin{array}{lll}\text { 8.3.6 Colorimetry } & 209\end{array}$

8.3.7 Colour points, colour temperature $\quad 214$

8.3.8 The colour characteristics of light sources 224

8.3.9 The colour rendering of light sources 229

$\begin{array}{lll}8.4 & \text { Gender specific aspects of vision } & 231\end{array}$

$\begin{array}{ll}\text { References } & 233\end{array}$

9 Visual performance, task performance $\quad 241$

$\begin{array}{lll}9.1 & \text { Visual performance } & 242\end{array}$

9.1.1 Law of Weber; primary visual functions $\quad 242$

9.1.2 Luminance discrimination 246

9.1.3 The contrast sensitivity $\quad 255$

9.1.4 The visual acuity 263

9.1.5 The speed of observation; flicker-effect 273

9.1.6 Detection of movement 279

9.1.7 The detection of point sources 280

$9.2 \quad$ Dazzle and glare $\quad 295$

9.2.1 Blinding glare 295

9.2.2 Disability glare 296

9.2.3 Discomfort glare 308

$\begin{array}{ll}\text { References } & 317\end{array}$

$10 \quad$ Fundaments of visual and behavioural functions 327

10.1 The philosophy of information processing 328

10.1.1 Out there and in here; the problem of knowledge 328

10.1.2 The nature of science 329 
10.1.3 The nature of sensory perception 332

10.1.4 Consciousness 333

10.1.5 The first level: the level of instincts. 337

10.1.6 Aggression 348

10.1.7 The second level: the level of emotions 356

10.1.8 The third level: the level of the ratio 361

10.1.9 The fourth level: the level of intuition 368

10.1.10 The four-level model of consciousness reconsidered 378

10.2 Perception of complex visual stimuli 380

$\begin{array}{ll}10.2 .1 \text { Gestalt aspects } & 380\end{array}$

10.2.2 Visual illusions $\quad 383$

10.2.3 Vigilance and attention 384

$\begin{array}{lll}10.3 & \text { The visual task in road traffic } & 387\end{array}$

10.3.1 Scenes, sequences and objects $\quad 387$

10.3.2 Expectancy 396

10.3.3 Priorities of observation 396

$10.4 \quad$ Motivation and decisions $\quad 401$

$\begin{array}{ll}\text { 10.4.1 Motivation } & 401\end{array}$

10.4.2 Decision making models $\quad 405$

10.4.3 Preview and the driving task; foresight in driving 408

References $\quad 415$

11 Technology and light-techniques $\quad 429$

11.1 The physical principles of light emission 430

11.1.1 The physics of light $\quad 430$

11.2 General aspects of outdoor lighting $\quad 443$

11.2.1 Outdoor lighting and light pollution 443

11.2.2 General issues of outdoor lighting design 444

11.2.3 Light control of the luminaires and lighting installation 447

11.2.4 Reflection from lighted surfaces and shielding of reflected light 447

12.2.5 Maintenance 448

11.2.6 Lighting for urban areas and residential streets $\quad 450$

11.2.7 Lighting of roads for motorized traffic 454

11.2.8 Lighting for outdoor sports 456

11.2.9 Lighting for outdoor work areas $\quad 459$

11.2.10 Other applications $\quad 460$

11.3 Lamps for outdoor lighting 461

11.3.1 Light emitting principle and groups of lamps 461

11.3.2 Lamps as an energy conversion device $\quad 462$

11.3.3 Incandescent lamps 464

$\begin{array}{ll}\text { 11.3.4 Discharge lamps } & 467\end{array}$

11.3.5 Fluorescent high-pressure mercury discharge lamps $\quad 470$

11.3.6 Metal halide lamps 471

11.3.7 Semiconductor lamps $\quad 472$

11.3.8 Features of lamps for outdoor lighting $\quad 472$

$\begin{array}{lll}11.4 & \text { Luminaires } & 474\end{array}$

11.4.1 General aspects of luminaires $\quad 474$ 
$\begin{array}{ll}\text { 11.4.2 Optical systems } & 478\end{array}$

11.4.3 Types of luminaires $\quad 481$

11.4.4 Luminous distribution curves of luminaires 486

$\begin{array}{lll}11.5 & \text { Supporting structures } & 486\end{array}$

11.5.1 General aspect of the supporting structure 486

11.5.2 Required characteristics of the supporting structures 488

11.5.3 Types of the supporting structures 488

11.6 Efficiency of outdoor lighting systems 496

11.6.1 Efficiency of elements of outdoor lighting systems 496

11.6.2 Electric efficiency of ballasts and dimming devices 498

11.6.3 Electro-luminous conversion efficiency of lamps 499

11.6.4 The luminous efficacy of lamps 500

11.6.5 The output ratio of luminaires $\quad 502$

11.6.6 The Upward Light Ratio 503

11.6.7 Relationship between OLOR and ULOR and the Upward Luminous Flux 504

11.6.8 Utilization factor and required lamp luminous flux 504

11.6.9 Lamps and luminaires combined; the efficiency of the lighting system 506

11.7 Elements of outdoor lighting design. 506

11.7.1 Traditional and low-pollution lighting design 506

11.7.2 CIE-based design methods for road lighting 508

11.7.3 Low light pollution design methods $\quad 512$

11.7.5 Examples of the simplified low light pollution design method 522

11.8 Visibility based design method for road lighting 524

$\begin{array}{ll}11.8 .1 \text { General aspects } & 524\end{array}$

11.8.2 Luminance contrast under road lighting conditions 526

11.8.3 Visibility based methods for road lighting design in the past 528

11.8.4 Experimental background of the visibility based design method 529

11.8.5 Theoretical background of Revealing Power based design for road lighting 533

11.8.6 Procedure for deriving distribution of Revealing Power 538

11.8.7 Relations between the Area Ratio and the lighting parameters 539

11.8.8 Road surface luminance for other than visibility 540

$\begin{array}{ll}\text { References } & 541\end{array}$

12 Effects of outdoor lighting on society and on the environment 547

$12.1 \quad$ Road lighting 548

12.1.1 Accident prevention 548

12.1.2. The relation between public lighting and crime prevention and reduction 563

12.1.3 Non-lighting studies about crime $\quad 583$

$\begin{array}{ll}\text { 12.1.4 Fear for crime } & 599\end{array}$

$\begin{array}{ll}12.1 .5 & \text { Amenity } \\ 12.1 .6 & 604\end{array}$

12.1.6 Urban beautification $\quad 608$

$\begin{array}{lll}12.2 & \text { Automobile lighting } & 612\end{array}$

12.2.1 Light pollution by vehicle headlamps. 612

12.2.2 The overall characteristics of vehicle lighting 613

12.2.3 Visibility when using car headlighting 616

12.2.4 The history of the low beam pattern 619

12.2.5 Recent developments in passing mode lighting 621 
12.2.6 Standards and regulations

12.2.7 Operational aspects of front lighting systems 631

12.2.8 Deviations in practice $\quad 636$

12.2.9 Influence of vehicle headlighting on light pollution 645

12.3 Cost benefit assessments of road lighting 646

12.3.1 Cost-benefit and cost-effectiveness $\quad 646$

12.3.2 Cost-benefit relations of road lighting $\quad 647$

$\begin{array}{ll}\text { 12.3.3 Quantification of accident costs } & 649\end{array}$

12.3.4 Costs of road lighting $\quad 651$

12.3.5 The cost/benefit ratios road lighting 651

$\begin{array}{ll}\text { 12.3.6 Conclusions } & 652\end{array}$

$\begin{array}{lll}12.4 & \text { Flat glass controversy } & 652\end{array}$

12.4.1 Upwards light emission $\quad 652$

12.4.2 Basic luminaire construction $\quad 655$

$\begin{array}{ll}\text { 12.4.3 Open luminaires } & 660\end{array}$

12.4.4 Optical considerations in luminaire design 663

12.4.5 Comparisons between luminaires with different cover shapes 669

12.4.6 Comparisons between installations with luminaires with different $\begin{array}{ll}\text { cover shapes } & 673\end{array}$

$\begin{array}{ll}\text { References } & 678\end{array}$

13 Environmental aspects of light pollution 695

13.1 Energy production and energy saving 696

$\begin{array}{ll}13.1 .1 \text { Greenhouse effect } & 696\end{array}$

$\begin{array}{ll}\text { 13.1.2 } \mathrm{CO}_{2} \text {-emission } & 706\end{array}$

13.1.3 Trends in energy usage $\quad 716$

$\begin{array}{ll}13.2 & \text { Energy for lighting }\end{array}$

13.2.1 Outdoor lighting $\quad 729$

13.2.2 Energy use for street lighting $\quad 729$

13.2.3 Luminous flux per inhabitant 731

$\begin{array}{lll}13.3 & \text { Energy losses as a result of light pollution } & 742\end{array}$

$\begin{array}{lll}13.4 & \text { Conclusions about environmental aspects } & 744\end{array}$

$\begin{array}{ll}\text { References } & 745\end{array}$

14 Photometry $\quad \mathbf{7 5 1}$

14.1 Photometry in engineering and in astronomy $\quad 752$

14.1.1 General aspects $\quad 752$

14.1.2 The ISO-photometry 756

$\begin{array}{ll}\text { 14.1.3 The luminous flux } & 758\end{array}$

$\begin{array}{ll}\text { 14.1.4 The luminous intensity } & 758\end{array}$

$\begin{array}{ll}\text { 14.1.5 The illuminance } & 760\end{array}$

14.1.6 The luminance $\quad 768$

14.1.7 The luminance of virtual objects $\quad 777$

14.1.8 The luminance factor $\quad 783$

14.1.9 Retroreflecting devices $\quad 786$

$\begin{array}{lll}14.2 & \text { Photometry in astronomy } & 798\end{array}$

14.2.1 Subjective and objective photometry 798 
$\begin{array}{ll}\text { 14.2.2 Subjective photometry } & 799\end{array}$

14.2.3 Objective photometry 804

14.3 Relation between photometry in engineering and in astronomy 816

14.3.1 Radiometry and photometry 816

14.3.2 Photometric units used in astronomy $\quad 817$

14.3.3 Magnitude loss as a result of outdoor lighting 818

14.3.4 Conversion of astrophysical and engineering units. 820

14.3.5 A general formula for the conversion 820

14.3.6 Conversion tables. $\quad 821$

$\begin{array}{lll}14.4 & \text { Light pollution and light immission } & 826\end{array}$

14.5 The measurement of light $\quad 828$

$\begin{array}{ll}14.5 .1 & \text { Detectors }\end{array}$

$\begin{array}{ll}\text { 14.5.2 CCDs } & 845\end{array}$

14.5.3 Measuring photometric quantities $\quad 852$

$\begin{array}{lll}14.6 & \text { Measuring light pollution } & 859\end{array}$

14.6.1 The values of the sky glow $\quad 859$

14.6.2 Simple area surveys $\quad 860$

14.6.3 Continuous surveys and sky glow monitoring 863

14.6.4 Site selection $\quad 864$

14.6.5 Accurate site monitoring $\quad 864$

14.6.6 Global measurements; satellite methods $\quad 864$

14.6.7 Measuring light trespass $\quad 865$

$\begin{array}{lr}\text { References } & 867\end{array}$

$15 \quad$ Public aspects $\quad 879$

15.1 Astronomy and lighting engineering in the world 880

$\begin{array}{lll}15.2 & \text { Outreach, public awareness } & 883\end{array}$

15.3 Education $\quad 890$

15.3.1 Training, teaching and education $\quad 890$

15.3.2 Classroom teaching of astronomy $\quad 894$

15.3.3 International School Education Networks 896

$\begin{array}{lll}15.4 \quad \text { Legal aspects } & 898\end{array}$

15.4.1 Light as a pollutant $\quad 898$

15.4.2 Enforcement of limiting values 900

15.4.3 Light intrusion; liability 903

15.4.4 Legal aspects of laser applications 906

$\begin{array}{lll}15.5 & \text { Standards, laws and regulations } & 907\end{array}$

15.5.1 National and international regulations. $\quad 907$

15.5.2 Frameworks for lighting codes 908

15.5.3 Examples of national legislation. $\quad 910$

$\begin{array}{lll}15.6 & \text { Site selection and protection } & 912\end{array}$

$\begin{array}{ll}\text { 15.6.1 Local ordinances } & 912\end{array}$

15.6.2 Outdoor lighting projects 916

$\begin{array}{ll}\text { References } & 921\end{array}$

$\begin{array}{lr}\text { Index } & 927\end{array}$ 


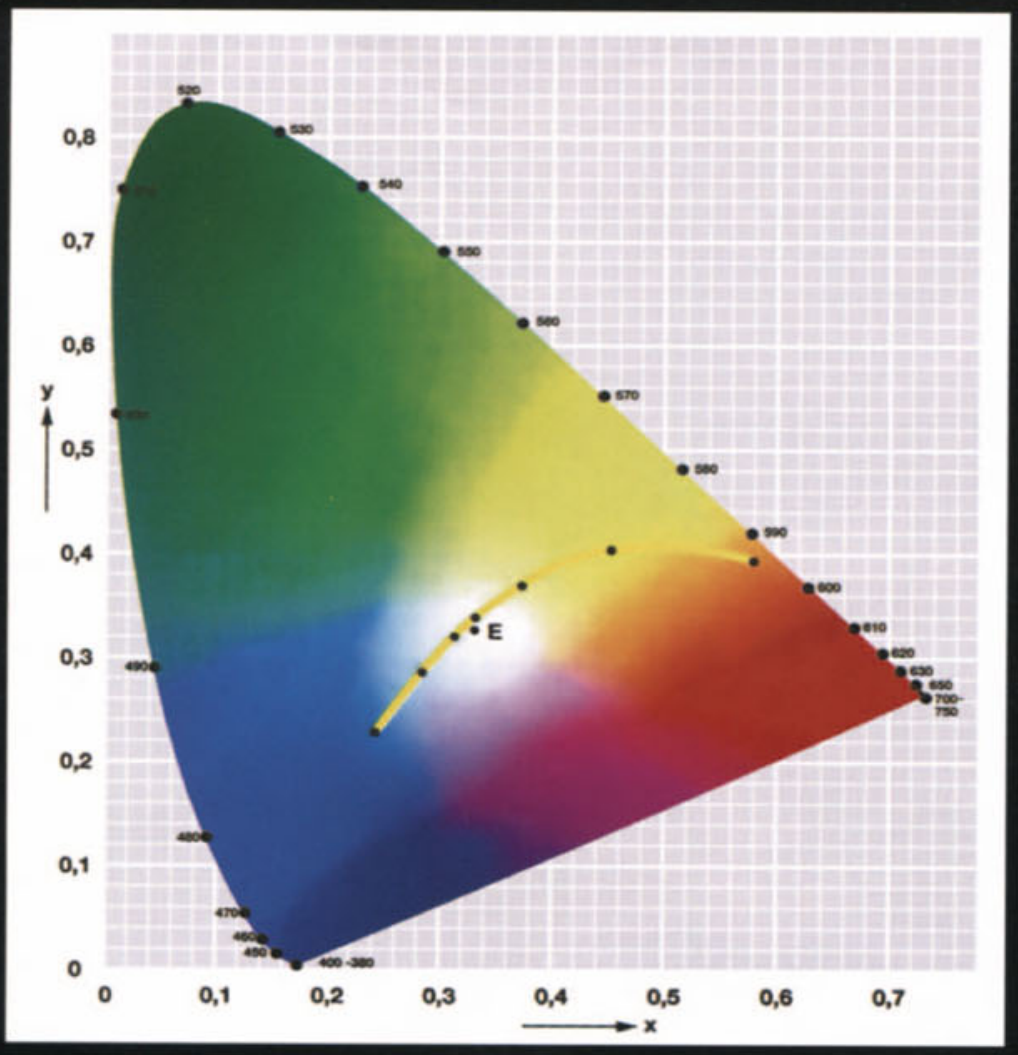

The CIE Colour Tiangle

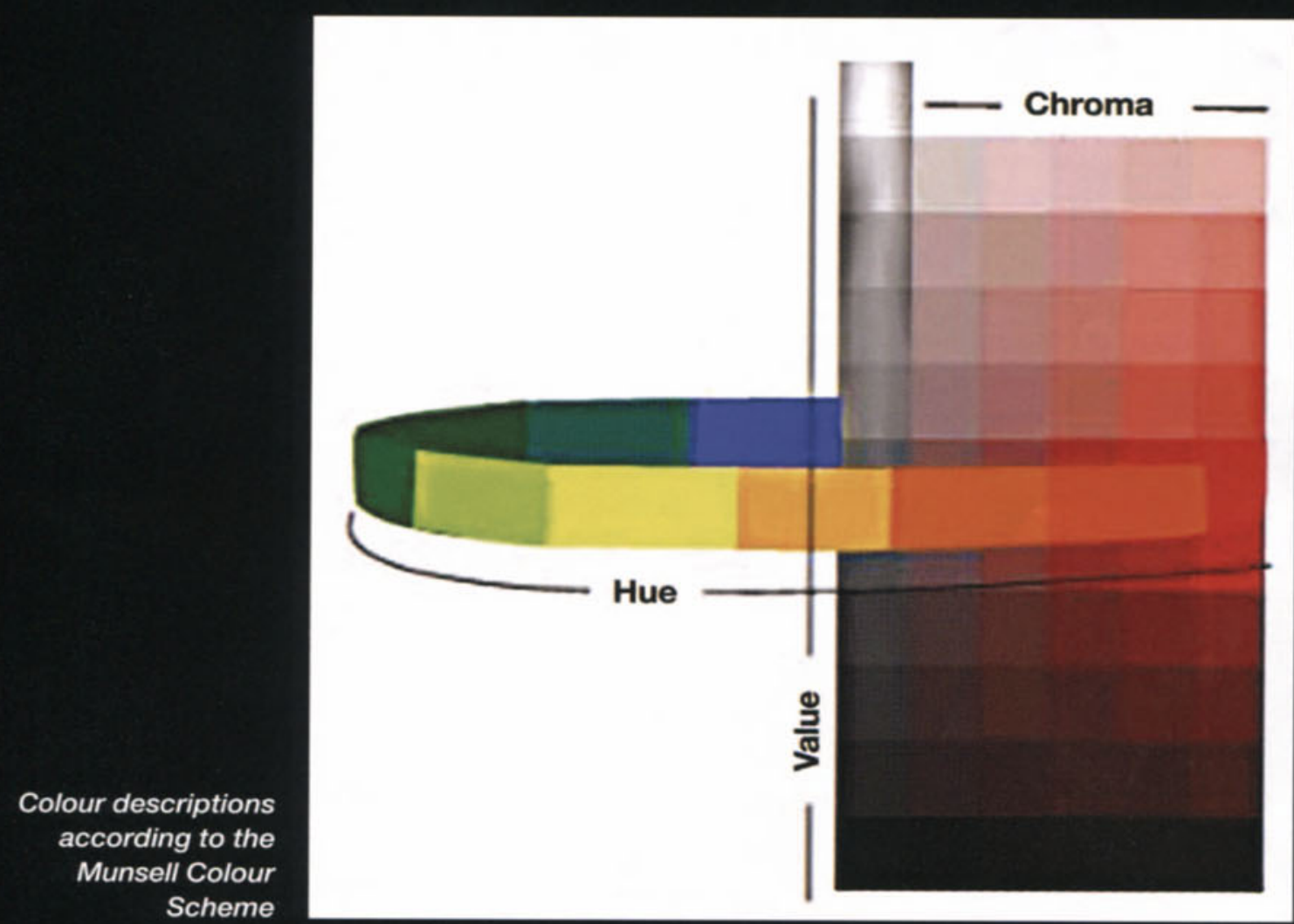




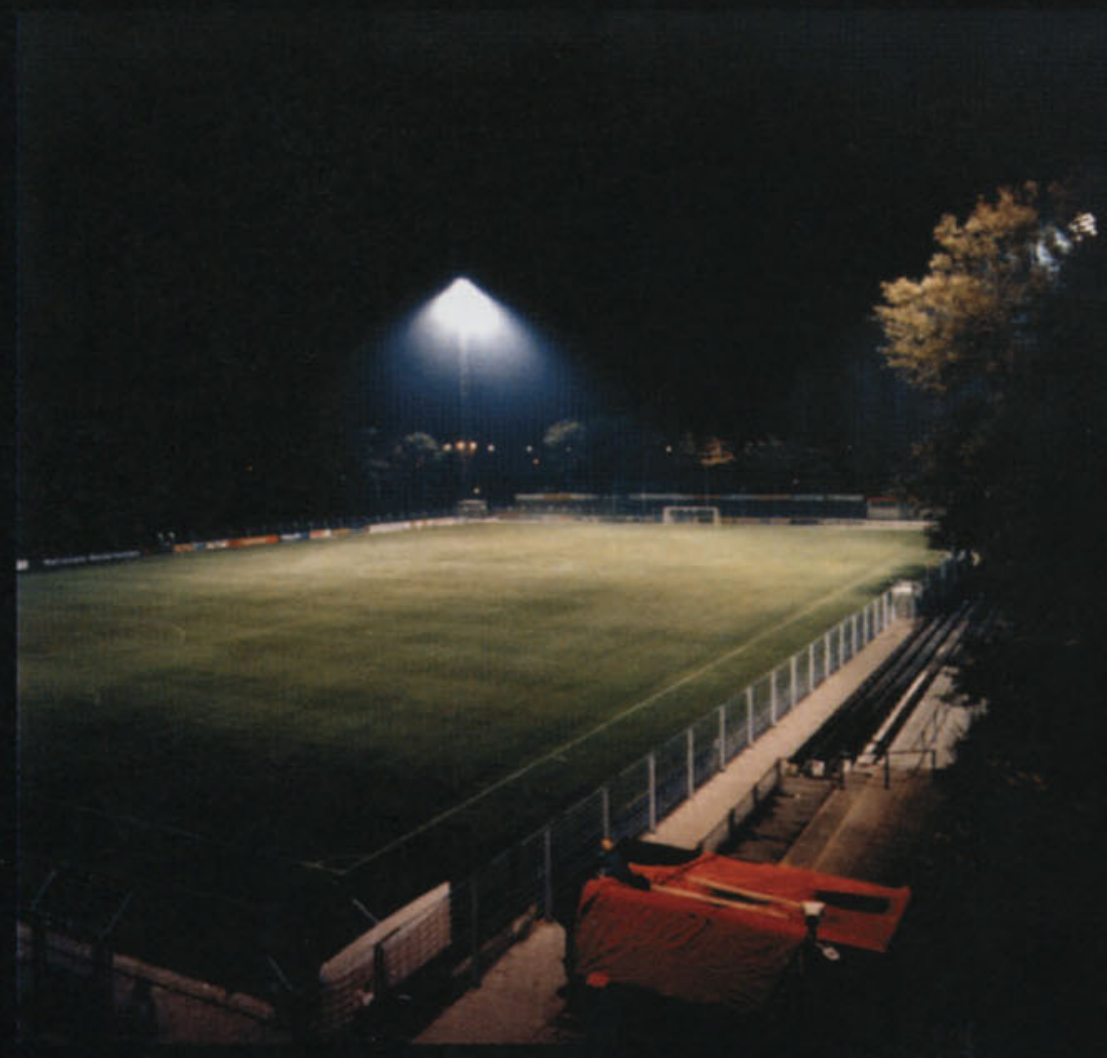

Example of a training field for soccer football 


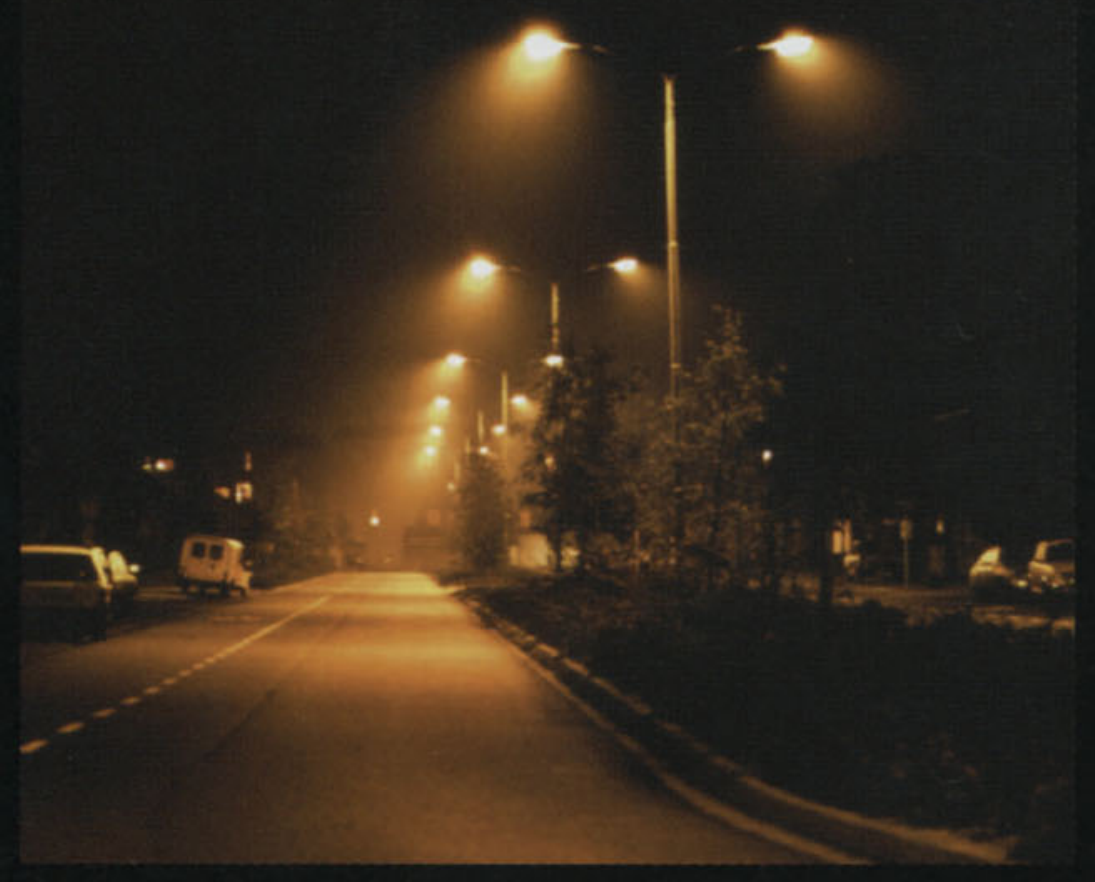

Road lighting with CIE cut-off lanterns

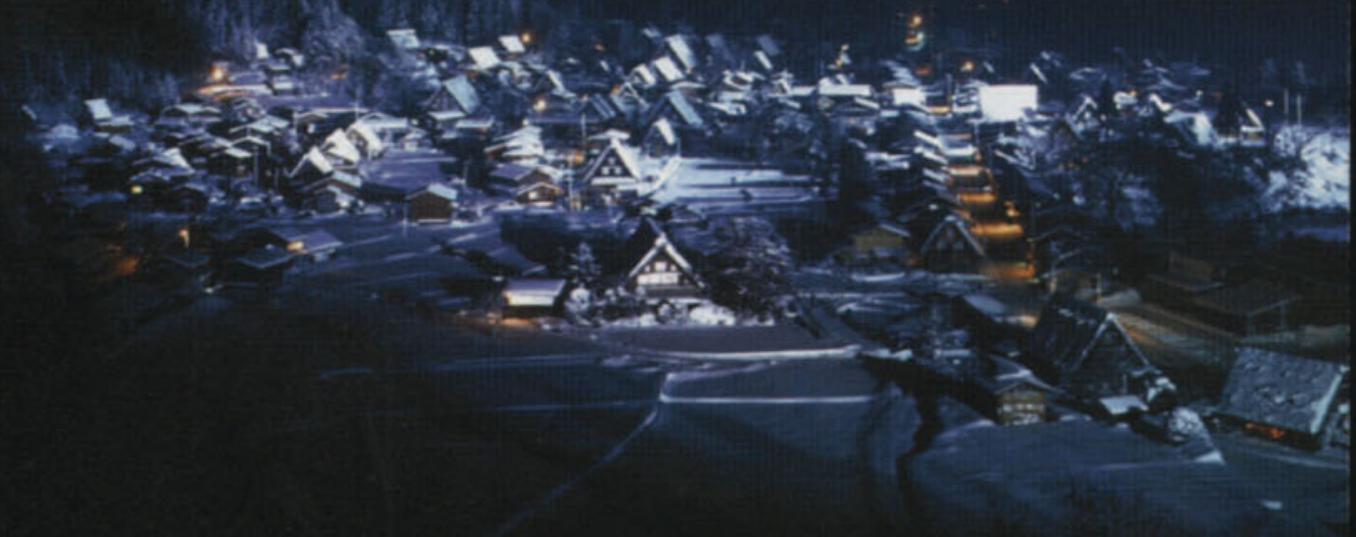




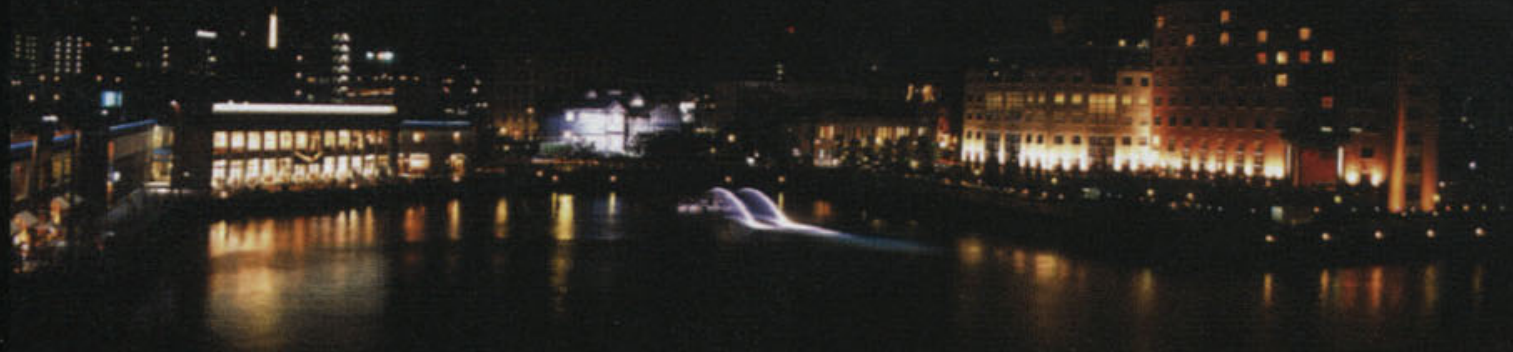

Decorative lighting for the historical port of Moji, Japan

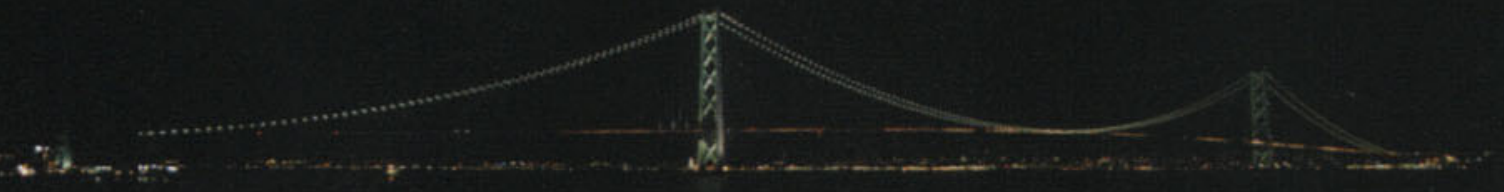

Illumination for Akashi-Kaiko bridge, Japan.

With $3911 \mathrm{~m}$ the longest suspension bridge in the world 


\section{Preface}

This book deals with light pollution and about the ways to reduce it. Light pollution is one of the negative side-effects of artificial outdoor lighting. The term light pollution is an unhappy one, but as no better alternative seems to exist, it will be used throughout this book.

The function of all outdoor lighting is to enhance the visibility or the aesthetics in the nighttime environment. The light should come where it is needed. If not, it is spilled, causing economic and environmental losses as well as disturbance and discomfort. The overall effects are termed 'light pollution'; a major form of light pollution is the glow extending over the night sky.

Sky glow is discussed in many astronomical textbooks and in many popular brochures. The present book is primarily aimed at those responsible for outdoor lighting installations. Thus, an engineering approach has been chosen. The level of the book is that of 'college' or 'University level'. The book is organized in two parts. The first seven chapters cover the areas of general interest, and conclude with recommendations. The second part deals with the scientific and engineering elaboration of the first part. A number of examples are included that refer to specific outdoor lighting installations and projects that are directly related to the reduction of light pollution. Finally, some information is given about the authors.

(a) About light pollution

This book deals with light pollution. It is understood that light pollution is one of the negative side-effects of outdoor lighting. As is explained in several chapters of this book, outdoor lighting is essential for our type of society to survive. The side-effects are real. It is one of the objectives of this book, to show that they can be reduced by technical and organizational methods, so that the disturbance caused by light pollution can be lessened.

A point that must be made clear right from the beginning, is the use of the term 'light pollution'. To begin with, the term is actually a mishap, probably originating from the similarity in words with 'air pollution' and 'water pollution'. In these cases, it is the air or the water that gets dirty. Light cannot, in the same way, get dirty. As is explained in several chapters of this book, light is not only beneficial, but it is essential for all life on Earth. As mentioned already, there are negative side-effects. Whether the side-effects 
must be regarded as 'pollution', however, depends on the concepts of nature, the environment and of the 'human condition' that are favoured.

\section{(b) About the book}

This book deals with light pollution in a very general sense. Its nature of a 'handbook' implies that most effects of light pollution will be discussed. Some details are not discussed; they will be indicated later in this section. The emphasis is on those aspects of light pollution that interfere with astronomical observations. As will be explained lateron, astronomers are a major victim-group of light pollution.

As is explained earlier, light pollution is one of the negative side-effects of artificial outdoor lighting. The outset is that all outdoor lighting is functional, its function being the enhancement of the visibility or of the aesthetics in the night-time environment. Light pollution represents a loss as regards electric energy. Good lighting design ensures that the light comes where it is needed, and does not fall elsewhere. If not, the light is 'spilled'. It may cause considerable economic and environmental losses. Furthermore, spill light from outdoor lighting installations often causes disturbance and discomfort for those that have nothing to do with the lighting. The light invades into the private sphere of people. This is 'intrusive light' or 'light trespass'. The overall effects are termed 'light pollution', with the proviso made in the foregoing part of this section.

One of the most conspicuous forms of light pollution is the 'sky glow' that extends over all near and distant sources of light pollution. Sky glow is the result of light that is projected upwards, and then scattered back to the surface of the Earth. Part of the light that is emitted by the light sources is directed straight up. Another contribution to the sky glow results from light that, after having been 'used', has been reflected upwards.

Sky glow is discussed in detail in a number of excellent textbooks that are listed in sec. 15.2a. These textbooks are almost exclusively written by and for experts, in most cases professional or advanced amateur astronomers. They are, however, hardly useful for the general public, for policy makers, and for the authorities that are responsible to uphold the quality of life. Apart from these textbooks, one can encounter a wide variety of articles, brochures and pamphlets that describe in great detail the adverse effects of sky glow and of light pollution in general. Several of these publications ar listed in the following sections of this book.

The present book tries to fill the gap that exists between the astronomical textbooks and the popular brochures. It is aimed at all people directly involved - full time or part time in outdoor lighting, people that come in contact with light pollution. It gives details of the different aspects that are relevant in dealing with the problems related to light pollution, its cause, and its reduction. The main audience of the handbook is the authorities that are responsible for the design, installation and maintenance of outdoor lighting installations, with a special reference to the resuction of light pollution effects. It is also aimed at the managers of astronomical observatories and at the authorities and decision makers 
responsible for the organization and maintenance of the public space. Also, it will serve a good purpose in education, particularly in graduate or postgraduate curricula for scientists, engineers, economists, and law students.

Thus, an engineering approach has been chosen, implying that the book aims at practical and economically feasible solutions for problems that are stated in scientific terms. The main characteristic of the engineering approach is that an optimum solution is looked for - often an attempt to reach a compromise between what different aspects would ideally require. As will be clear in several sections of this book, subjective elements may play some role in reaching the optimum. In this way, the engineering approach differs from the approach that aims at maximization - an approach that is often used in studies related to the natural sciences. Both the engineering approach and the natural-sciences approach are, however, based on scientifically valid data.

The level of the book corresponds to this audience. The level might be characterised as 'college level' - or University level for European audiences. Details that are time-sensitive or controversial are not put on the foreground, to ensure that the book is not out of date too soon and that it remains readable for readers of different outlooks. This does not mean that it is strictly objective; the personal opinions and preferences of the authors may be gleaned when looking closely at the text.

The book is to a large extent based on the investigations that have been made by the authors themselves. This means that there is an emphasis on the results of studies that were made in Japan and in the Netherlands respectively. This preference is supported by the fact that in the area of outdoor lighting, Japan and the Netherlands have always made large contributions. One of the reasons for this is that these countries are the home of several of the most important lighting industries in the world. It goes without saying that in many respects the contribution of other countries is just as important. When conceiving the book, great care is made to present the material in a fashion that guarantee a world-wide use for the book.

The different aspects of light pollution and of sky glow are dealt with in different degrees of detail, so as the subject requests. Mathematical arguments are restricted to a minimum. As far as feasible, reference is made to more detailed studies. Also, the wide subject of light scatter in the atmosphere is not dealt with. Neither are the technical details of outdoor lighting design, nor the details of legislation and regulation. These subjects are very relevant, but it was felt that they are too specialized for a more general readership. Nither are cost aspects dealt with in detail. This refers to the costs of light pollution and the costs of the implementation of light pollution countermeasures. The reason is three-fold. First, the costs of light pollution are only in part of a monetary nature. Second, costs estimates vary very much in time. Precise indications would make the handbook obsolete in a short time. And third, probably the most important, cost aspects vary very much between different areas in the world. So is energy, including electric energy, much cheaper in the US than in almost all other countries of the world. When the costs are compared to the 
GNP of a country, the differences are much larger. As an example, we might compare the USA with Tanzania, one of the poorest countries in the word. In the USA, the per capita GPN is US\$ 24750 , in Tanzania US\$ 90 (1993 data). With a price of electric energy per MWh of 5 and 10 US $\$$ respectively, the US citizen has to work 0,323 hours for one MWh, whereas the Tanzanian must work 89 hours for that - well over two weeks. Because there is so little ground for an easily comparison, cost considerations are dealt with only in summary in this handbook. A comprehensive bibliography is included at the end of each chapter of the book. This approach is reflected in the structure of the book.

As regards optical astronomy, light pollution is not its only disturbance. Important sources of man-made interference with astronomical observations are passing aircraft, contrails (the vapour trails left by passing aircraft), satellites and space debris. Furthermore, vibrations and dust - e.g. from nearby mining activities - may have adverse effects. In earthquakesensitive areas, geophysical disturbances may pose serious difficulties. These disturbances are not dealt with in this book. For obvious reasons, radio astronomy and the many disturbances like interference by radio and television broadcasts by electromagnetic disturbances in general, are not dealt with either. We will, however, give some references that may serve the interested reader. To begin with, it did almost become a tradition that conferences on interference of astronomical observations discuss as the three main items: light pollution, radio interference, and space debris. The proceedings of such conferences give a considerable amount of further information. See for these aspects Cohen \& Sullivan, eds. (2001); Crawford, ed. (1991); Isobe \& Hirayama, eds. (1998); Kovalevsky, ed. (1992); McNally, ed. (1994); Schwarz, ed. (2003).

Passing aircraft and contrails are discussed in some detail in Pedersen (2001). The lights of the aircrafts themselves may damage CCD receivers (Kovalevsky, 1992, sec. 6.5), whereas the heat from the aircraft exhaust may reduce the 'seeing' (Pedersen, 2001, p. 174). After the passage of the aircraft, condensation trails ('contrails') may form that interfere with astronomical observation. Contrails are understood to increase the overall cloudiness world-wide by $0,1 \%$ and in Europe by $0,5 \%$. In general, they do not seem to be a serious threat for astronomical observations, but it seems that under special meteorological circumstances, their influence is much bigger (Anon., 2002). It is estimated that in most parts of Western Europe, more than 1 to $2 \%$ of the noon-time sky is covered by 'young' persistent contrails, whereas the larger part of continental USA is covered for over $2 \%$ (Pedersen, 2001, figure 1, based on data from Mannstein et al., 1999). It is therefore recommended to select sites for observatories far away from air routes (Pedersen, 2001, p. 177).

Geophysical disturbances have been discussed in some detail in Anon. (1984). See also Barlier \& Kovalevsky (1992). The matter is very topical in view of the fact that some of the major observatories in the world, like e.g. Cerro Paranal in Chile and Mauna Kea in Hawaii, are built on more or less active volcanoes, where the region is by nature earthquake-sensitive. 
(c) The organization of the book

The book is organized in two main parts. The first part covers the areas of general interest. It includes a general discussion of the problems of light pollution and a survey of the remedial measures. It also gives recommendations. It is aimed at al people directly involved - full time or part time - in light pollution, the main audience being be the authorities and decision makers responsible for the organization and maintenance of the public space. This part ends with recommendations that are aimed at minimizing the negative aspects of light pollution.

The second part, from Chapter 8 onwards, deals with the scientific and engineering elaboration of the material covered in broad lines in the first part. There is some overlap between the two parts. The second part is aimed at professional scientists and engineers, such as the managers of astronomical observatories, the designers of lighting equipment, and the installateurs of lighting installations. Mathematical arguments are restricted to a minimum. Both first and second part may serve for graduate or postgraduate curricula for scientists, engineers, economists, and law students.

Two points must be clarified. The first regards the language of the book. The authors did all they reasonably could do to ensure that the meaning is made clear to the reader; although they tried to do this in UK-English, it should be realised that some JapaneseEnglish and Dutch-English crept in, in spite of the efforts of Mr Stephen Harris, who checked the language. The authors wish to apologize if this leads to some obscurity.

The second point refers to the problem of the decimal sign. The authors used the ISOstandard for writing numbers, which means that the 'comma' is used for the decimal sign and a space between powers of one thousand. This agrees to the international ISO Standard ISO 31-0:1992 'Quantities and units - Part 0: General principles'. In section 3.3.2 of that standard, it is stated: "The decimal sign is a comma on the line. If the magnitude of the number is less than unity, the decimal sign should be preceded by a zero" (ISO, 1992, p. 11). This ISO-standard is followed by the great majority of scientific organizations and standardizing organizations worldwide, more in particular by CIE and CEN. In view of the fact that this book is aimed at a world-wide readership, and also to help to promote the use of international standards, this system was adopted in this book, in spite of the fact that IAU and some countries like UK and USA do otherwise.

\section{(d) About the authors}

Kohei NARISADA was born on 28 November 1929 in Kyoto. He obtained his degree in electrical engineering at Doshisha University, Kyoto, Japan. On joining Matsushita Electric in 1953, he was involved in lighting design at the Lighting Division. In 1962, he transferred to the newly established Lighting Research Laboratory and was involved in investigations concerning road and tunnel lighting. Between 1976 and 1989, he was head of the Lighting Research Laboratory. In 1976, he obtained a doctor degree (Engineering) at Kyoto University on tunnel entrance lighting. Between 1987 and 1991 he was the president of Japanese National Committee of CIE. After his retirement from 
the company in 1989, he became a professor of the Psychology Department at Chukyo University, Nagoya, Japan and was teaching visual perception in relation to road lighting. In 2003, he retired from the University. He is the honorary member of the Illuminating Engineering Institute of Japan, and a Chartered Engineer of CIBSE, UK. He became involved in international activities of Technical Committees of CIE on road and tunnel lighting in 1967. Since then, he is the member of a number of CIE technical committees on road and tunnel lighting, the chairman of the sub-committee on tunnel lighting. He is also a member of CIE technical committee dealing with the countermeasures for light pollution. Since 1979, he served a term as a member of the CIE Action Committee; he has been the Director of Division 7 and between 1991 and 1999 he was a Vice President of CIE. He is the co-author of several books and a great many scientific and technical papers.

Duco Anton SCHREUDER was born 1931 in Rotterdam, the Netherlands. In 1949 he graduated from the classical secondary school in Breda. After his national service from 1952 to 1954 as an officer in the Meteorological Service of the Dutch Royal Air Force, he took a masters degree in applied physics from the Delft University in 1958. In 1964, he was awarded a Doctorate of Technology from the Eindhoven University. In 1972 he took a masters degree in philosophy (specialization psychology) at the Haarlem International Institute. From 1958 to 1968 he was a research scientist at the Lighting Laboratories of Philips in Eindhoven. From 1968 to 1993 he was a Senior Researcher with SWOV Institute for Road Safety Research in Leidschendam. Since 1993 he is an independent consultant in the general fields of lighting and safety. Dr Schreuder is the author and co-author of several books and well over 300 scientific publications. He was and is the Chairman or member of a large number of national and international institutions and working groups, particularly in the Commission Internationale de l'Eclairage CIE, in the Comité Européen de Normalisation CEN, and in the Organization for Economic Cooperation and Development OECD.

The authors first met in the early 1960's, when their work on tunnel lighting lead in a natural way to an exchange of ideas and later to close cooperation. This cooperation was extended to most areas of outdoor lighting, focussing the last decade on matters of light pollution and of the interference by light of astronomical observation. The present book is a fruit of this decade-long cooperation of the two authors.

(e) Abbreviations

In this book, a number of abbreviations are used. Most of them are listed here, although many are explained in the text where they show up. The translations given here are indicative only. Most are not authorised; they are given only for matters of information. 


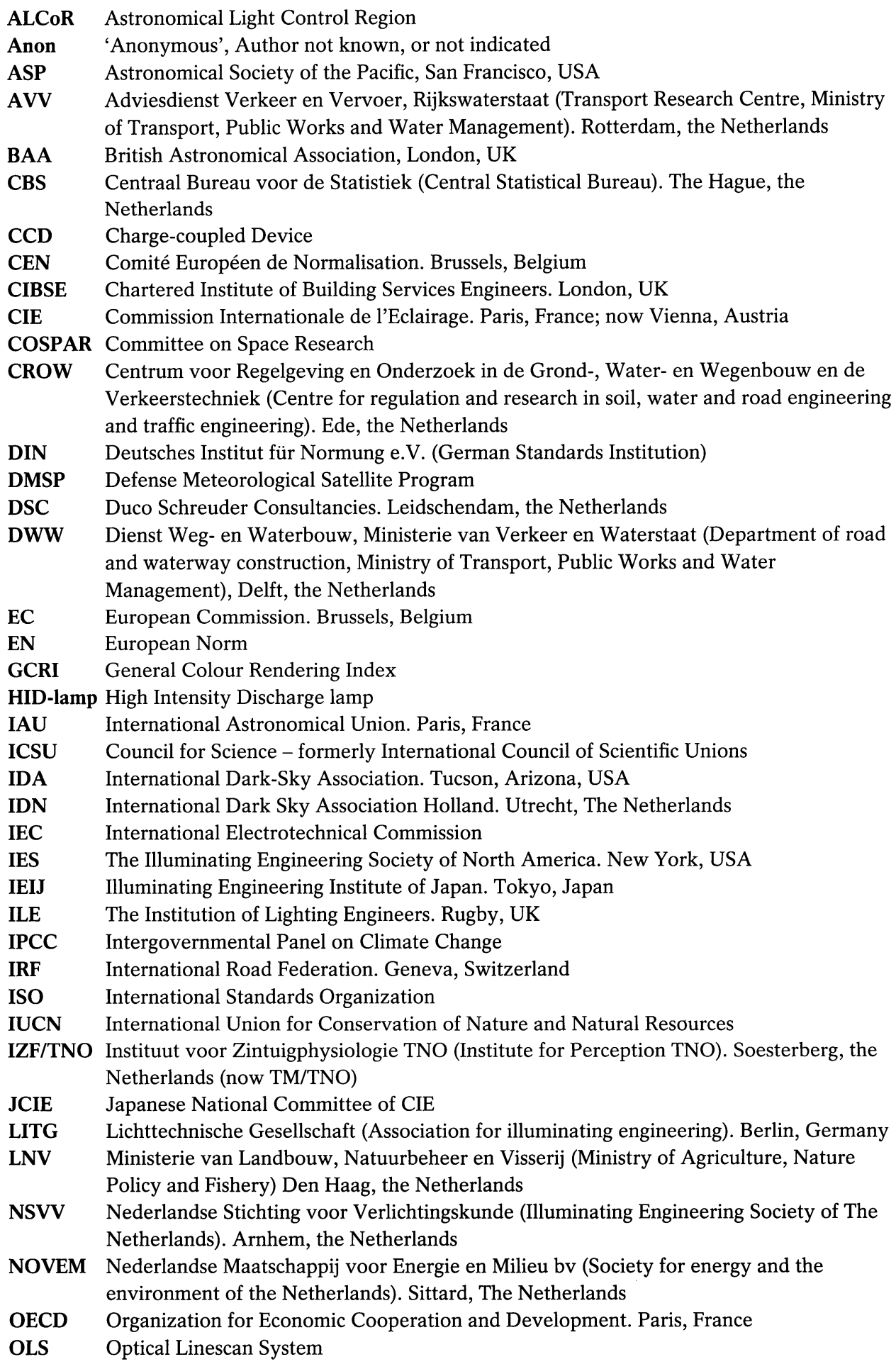


PAOVV Orgaan voor postacademisch onderwijs in de vervoerswetenschappen en de verkeerskunde. (Organisation for post-graduate studies in transportation sciences and traffic engineering). Rijswijk/Delft, the Netherlands

PrEN European Pre-Norm

RHT retinohypothalamic nerve tract

SANCI South African National Committee on Illumination

SCOPE Scientific Committee on the Problems of the Environment

SCOSTEP Scientific Committee on Solar Terrestrial Environment Problems

SCRI Special Colour Rendering Index $\mathrm{R}_{\mathrm{i}}$ for an individual colour

SCW Studiecentrum Wegenbouw (Study Centre for Road Construction SCW). Arnhem, the Netherlands (now CROW)

SCN suprachiasmic nucleus

SVT Stichting Studiecentrum Verkeerstechniek (Study Centre for Traffic Engineering) Driebergen, the Netherlands (now CROW)

SWOV Stichting Wetenschappelijk Onderzoek Verkeersveiligheid (Institute for Road Safety Research). Leidschendam, the Netherlands

TRB Transportation Research Board. Washington, DC, USA

TRRL Transport and Road Research Laboratory. Crowthorne, Berks., UK (now TRL)

UNESCO United Nations Educational, Scientific and Cultural Organization

V\&W Ministerie van Verkeer en Waterstaat (Ministry of Transport, Public Works and Water Management). Den Haag, the Netherlands

VNM Vereniging Natuurmonumenten - formerly Vereniging tot Behoud van Natuurmonumenten (the Society for the Preservation of Nature Monuments).

's Graveland, The Netherlands

VROM Ministerie van Volkshuisvesting, Ruimtelijke Ordening en Milieubeheer (Ministry of Public Housing, Land Planology and Environmental Policy). Den Haag, the Netherlands

WHO World Health Organization. Geneva, Switzerland

WVC Ministerie van Welzijn, Volksgezondheid en Cultuur (Ministry of Well-being, Public Health and Culture)

WWF World Wildlife Fund

\section{(f) Acknowledgements}

For a number of subjects, advise is asked from experts in different areas that fall outside the expertise of the authors. The two authors are, however, fully responsible for the contents of the book. In this respect, the authors want to extent their sincere thanks to many persons or institutions who were generous with their advise and comments. Many, but not all, are listed here, in alphabetical order.

Ms E.M. Alvarez del Castillo, for her very many and valuable suggestions and contributions to the book in different stages

Dr John Caldwell, for various suggestions

Dr D.L. Crawford, for his contribution on IDA, and for numerous suggestions

Mr F.J. Diaz-Castro, for his contributions on the assessment of sky glow

Mr G.C. Ederveen, for the careful reading of the text of the book

Dr R.H. Garstang, for his many valuable suggestions on the quantification of sky glow

Ms Sonja Japenga and Dr J.J. Blom of Kluwer Academic Publishers, for the help in the realization of the book 
Mr S. Harris, for the careful check on the UK-english of the book

Ms Motoko Ishii, for the permission to use photographs

Dr S. Isobe, for his valuable and numerous suggestions about the assessment of sky glow

Ms Yoko Kanii, for her kind help in preparing the colour photographs of Mrs. Motoko Ishii

Dr D. McNally, for his contribution on IAU and ICSU

Dr Margarita Metaxa, for her valuable suggestions and support on matters of general and classroom education

Mr A.L. Mierenet, for various suggestions

Dr Paolo Soardo, for his contributions on the assessment of sky glow

Dr B.E. Schaefer, for his contributions on unaided eye star viewing

Ms A. Rommers-Jong, for the valuable information about the international standards on the use of the decimal sign

Mr Paul Rutte, for the permission to use photographs

Mr Wim Schmidt, for his many valuable suggestions on different aspects of light pollution

Mr R.A.F. Schmidt, for his contributions on legal aspects of laser applications and for various other suggestions

Dr H.E. Schwarz, for his suggestions on measuring sky glow

$\mathrm{Mr} \mathrm{H}$. Stolk, for the many discussions and suggestions on the philosophy of light pollution

Mr Peter ten Hoor and Mr Jan Faber of LINE UP tekstprodukties bv, for the many valuable suggestions and for the excellent lay-out work of the book

Ms P.M. Van Bergem-Jansen, for various suggestions

Mr W.J.M. Van Bommel, for the permission to quote from the Opstelten-study

Ms W.M.H.E. Van Den Berg for her valuable contributions on the public health effects of light pollution

Mr Stan Vermaelen, for his contributions on image processing.

\section{References}

Anon. (1984). La protection des observatoires astronomiques et geophysiques (The protection of astronomical and geophysical observatories). Rapport du Groupe du Travail. Institut de France, Academie des Sciences, Grasse, 1984.

Anon. (2002). Condensstrepen - lijnen van ijs (Condensation trails - lines of ice). Grasduinen, mei 2002, p. 31.

Barlier, F. \& Kovalevsky, J. (1992). 'Pollution of geophysical sites'. In: Kovalevsky, ed., 1992. Chapter 5, p. 124-142.

Cohen, R.J. \& Sullivan, W.T., eds. (2001). Preserving the Astronomical Sky, IAU Symposium No. 196, held in Vienna, Austria, 12-16 July 1999. PASP, San Francisco, 2001.

Crawford, D.L., ed. (1991). Light pollution, radio interference and space debris. Proceedings of the International Astronomical Union colloquium 112, held 13 to 16 August, 1989, Washington DC. Astronomical Society of the Pacific Conference Series Volume 17. San Francisco, 1991.

ISO (1992). ISO Standard ISO 31-0:1992 "Quantities and units - Part 0: General principles".

Isobe, S. \& Hirayama, T. eds. (1998). Preserving of the astronomical windows. Proceedings of Joint Discussion 5. XXIIIrd General Assembly International Astronomical Union, 18-30 August 1997, Kyoto, Japan. Astronomical Society of the Pacific, Conference Series, Volume 139. San Francisco, 1998. 
Kovalevsky, J. (1992). Satellites, space debris, aircraft and astronomy. In Kovalevsky, ed., 1992). Chapter 6, p. 143-158.

Kovalevsky, J., ed. (1992). The protection of astronomical and geophysical sites. NATO-committee on the challenges of modern society, Pilot Study No. 189. Paris, Editions Frontières, 1992.

Mannstein, H. et al. (1999). Int. J. Remote Sensing, 20 (1999) 1641-1660 (Ref. Pedersen, 2001).

McNally, D., ed., (1994). Adverse environmental impacts on astronomy: An exposition. An IAU/ICSU/UNESCO Meeting, 30 June-2 July, 1992, Paris. Proceedings. Cambridge University Press, 1994.

Pedersen, H. (2001). Aviation and jet contrails: Impact on astronomy. In: Cohen \& Sullivan, eds., 2001. p. 173-178.

Schwarz, H.E., ed. (2003). Light pollution: The global view. Proceedings of the International Conference on Light Pollution, La Serena, Chile. Held 5-7 March 2002. Astrophysics and Space Science Library, Volume 284. Dordrecht, Kluwer Academic Publishers, 2003. 